\title{
Assessment of the development level of corporate social responsibility of a company
}

\section{Lesia Zaburanna ${ }^{2}$, Halyna Tarasiuk ${ }^{1}$, Tetiana Mostenska², Yaroslav Laguta ${ }^{1}$, Svitlana Bilan ${ }^{2}$}

\section{1 - Zhytomyr State Technological University, Zhytomyr, Ukraine \\ 2 - National University of Life and Environmental Sciences of Ukraine, Ukraine 3-Rzeszow University of Technology, Rzeszow, Poland}

Keywords:
Company
Responsibility
CSR

\section{Article history:}

Received 23.01.2020

Received in revised form 16.05.2020

Accepted 30.09.2020

\section{Corresponding} author:

Lesia Zaburanna

E-mail:

zaburannal@gmail.com

DOI: $10.24263 / 2304-$

974X-2020-9-3-16

\section{Abstract}

Introduction. It has been analyzed the existing methodologies for the assessment of corporate social responsibility (CSR) efficiency.

Materials and methods. For the current studies of the level of the enterprise's CSR development were used qualitative and quantitative methods of study for Ukrainian food processing enterprises. The CSR must be assessed by directions. Each of these levels has its own system of quantitative and qualitative indices and different methods, which may be used.

Results and discussion. The paper proposes the improved methodology for the determination of the CSR efficiency integral index, which is calculated by using the system of qualitative and quantitative parameters of the CSR assessment, which unlike the existing ones, take into account the indices of the internal and external CSR form.

The quantitative parameters of the internal CSR include such groups as the satisfaction of owners' interests through the company's profitability (the coefficient of changing the assets profitability), the satisfaction of personnel's interests (the coefficient of changing the employees' average monthly salary), the social investments on internal programmes (the coefficient of changing the expenses on internal social programmes), personnel development (the coefficient of changing a part of employees who completed re-training courses or advanced training), etc. The quantitative parameters of the external CSR include such groups as the social investments in outdoor environment (the coefficient of changing the expenses on external social programmes), the social investments on ecological programmes (the coefficient of changing the expenses on ecological programmes). The value of the coefficient of qualitative parameters is calculated according to the enterprise's CSR development level at the moment of the research.

Conclusion. The value of the integral index allows determining the level of the enterprise's CSR development and work out the system of measures for the development of the company's social activities. 


\section{Introduction}

Many scientific works are dedicated to the issue of corporate social responsibility (CSR) of companies as well as CSR efficiency assessment. However, these researches mostly deal with two principal approaches to the enterprises' CSR assessment: by quantitative and qualitative indices of social activities and influencing upon financial and production indices. Thus it is necessary to choose those methods and methodologies which will allow conducting the qualitative and quantitative assessment for the state of internal and external CSR, and the integral assessment will serve for the comparison and determination of the company CSR efficiency. G. Bowen considers the corporate social responsibility for an entrepreneur to be "the implementation of such a policy, making such decisions or observance such a behavior, which would be desirable for the purposes and values of a society".

There is the need to develop the complex methods for the company CSR assessment and the obtained results can be used both in the corporate social activity management and when forming the companies' ratings. And this causes the particular relevance and practical value for studying the current issues.

\section{Materials and methods}

\section{Materials}

The object of the study is the process of assessing the level of development of the corporate social responsibility of the Ukrainian food industry enterprises.

The subject of the study is determining a system of indicators that will allow estimating the state of corporate social responsibility, taking into account the sectoral peculiarities of activity of the food industry enterprises.

The calculations on Integral index of CSR efficiency were tested on five companies of food industry for 2015-2017 years:

1. JSC «Zhytomyr Butter Processing and Packing Factory», sity Zytomyr, Ukraine;

2. JSC «Zhytomyr Integrated Bakery», sity Zytomyr, Ukraine;

3. LLC «Organic Milk», sityBaranivka, Zytomyr region, Ukraine;

4. LLC «Zhytomyr Meat Processing and Packing Factory», sity Zytomyr, Ukraine;

5. JSC «Beer-Alcohol-Free Plant «Radomyshl'», sity Radomyshl', Zytomyr region, Ukraine.

\section{Methods}

The research is based on the use of general scientific and special methods, i.e. strategic analysis is used to determine the impact of corporate social responsibility initiatives on the strategic position of the enterprise [5]; factor analysis is used to determine the direction and strength of the impact of individual factors influencing the development of corporate social responsibility $[10,26]$; analysis and synthesis is implemented to develop a system of indicators and structuring the components of indicators to assess the level of development of corporate social responsibility $[8,28]$; rating assessments is applied to assess the business reputation of companies [20,21]; peer review is used to determine the compliance with mandatory legal requirements and business ethics, the level of charitable and / or sponsorship activities, the level of responsibility of the company to internal and external stakeholders. 


\section{Literature analysis}

G. Bowen considers the corporate social responsibility for an entrepreneur (Bowen, 1953) [1]. The role of CSR has been constantly increasing more and more in the development of society for several past years (Bartok, 2018; Burianová \& Paulík, 2014) [2,3]. Scientists pay a lot of attention to the issues of social responsibility of business, its role in the solution of social, ecological problems of society (Khoma, Moroz, Horyslavets, 2018) [4], the study of connection between the CSR efficiency and financial indices, the maximization of value for stakeholders etc. (Rajnoha, Lesnikova, 2016) [5]. All these issues are more or less determined by the CSR development level. However, the character of interrelation between the interests of business and society, stakeholders has not been examined enough yet (Freeman, Harrison, Wicks, 2007) [6], Agle et al. (2008) [7], Schwartz \& Carroll (2008) [8].

However many scientists consider that the theory of interested parties is connected to the impact of the initiatives on the management of stakeholders (Harrison, Bosse, Phillips, 2010) [9].

More questions and discussions appear when forming specific indices, which are used for measuring the CSR development level, the level of influence of social initiatives on social efficiency, corporate financial results. The issue of individual and corporate social responsibility, the impact of any initiative on strategic decisions were the subjects of scientific research (Bénabou, Tirole, 2010) [10].

The existing connection between the CSR development level and financial indices are introduced in modern investigations by many scientists (Bettis, Helfat, Shaver, Zhao, Murrell, 2016; Shahzad, Sharfman, 2017) [11,12].

In 1974 American scientists published the book "Unsteady Subsoil: Social Policy of Corporations in a Dynamic Society" while researching the issue of companies' CSR assessment (Robbins, Coulter, 1974) [13], where they singled out four approaches (methods) to the company CSR assessment. The first method involved the use of social indicators, the determination of living standard index through the calculation of quantitative indices and the assessment of corporations' social activity impact on this index (they are the indices of labour protection state, health protection state, and others), in particular. The second method was in developing the system, which included the assessment of expenses for the social programmes, their implementation, and their efficiency assessment as well. In F. Kotler's point of view, the CSR benefits are impossible to measure and the most companies do not disclose the expenses at such activities, and that is why it is impossible to measure the recoupment of such investments. The third method included carrying out the assessment through making up socalled social report, where the benefits for employees, customers, suppliers, community, and other stakeholders, the social expenses of a firm for providing these benefits were presented in the balance form. The fourth one is the method of ranking companies according to their social activities. First two approaches allow examining the CSR assessment from the point of view of external and internal CSR. Hence, in accordance with the significant expenses on social goals, we face the CSR efficiency assessment issue. The majority of advanced companies and consultants of the USA follow "a social audit", which focuses on how the company social behavior reflects on business indices. The methodology developed by the consulting company SmithOBrien requires the integrated activity assessment by the following principal systems of economic and social indices as the quality management system, energysaving, and environmental protection, relations with personnel, human rights, and relations with local community (Nikitina, Borzakov, 2015) [14]. This methodology is the corporate stability audit integrated system implemented in all the international systems of social 
responsibility ratings. As for the third approach, in our opinion, the availability of the social report itself can be examined as one of the CSR integrated assessment criteria. It is well known that the most used international standard for preparing the social reporting is the Global Reporting Initiative (GRI, 2015) [15]. This standard includes a sufficient amount of indices, but it does not deal with obtaining any common value of social responsibility level. The essential drawback of this standard is the application of various indices, expensive, natural, absolute, and relative. However, the advantage of the standard is increasing the prestige of company in the eyes of society that results in growing demand, consumers' credit, and finally increasing the products of company activities. It is important to publish and place the social reporting of companies on their web sites, present it on conferences, public events, even to issue brochures etc. Reporting is the main source of information about the company CSR.

These three approaches provide an opportunity to assess each component of social responsibility separately, but make it impossible to assess the general level, and compare companies quantitatively. For this purpose, the above-mentioned rating approach is used. In addition, competitions and ratings must be maximum transparent and open as well as their organization performance must be professional, responsible, and sustainable (prestige, reputation, independence etc.).

Nowadays, reputation ratings are used in the world (the fourth approach). The rating method involves ranking the group of companies with similar type of activities by determined criteria. Professionals of any field of research, groups of consultants, public organizations, independent experts etc. can function as experts. The rating of companies' business reputation for all the countries, but the USA, has been composed since 1997 by Hoy Groupp agency. The experts assess over 300 companies. The assessment is carried out on innovations, personnel, using corporate assets, social responsibility, management quality, financial sustainability, long-term investments, the quality of products and services. Among the first ones there are companies, which know how to build up their relationships with stakeholders, i.e. the first places are not always given to the companies with the highest amount of sales, income etc. (Beliaeva, Eskindarova, 2016) [16].

Most scientists involved in studying the issues of assessment of corporate social responsibility development level consider that the CSR must be assessed by directions and different methods may be used simultaneously. They single out personnel and its development, environmental protection activities, health protection and working conditions, the development of communities, resource-saving, and business practice. And each of these directions has its own system of quantitative and qualitative indices.

Vorona (2010) has the same opinion and adds that it is necessary to single out the following four directions: personnel, business, a society, and an image, and determine corresponding indices for the CSR assessment [17]. Levyts'ka (2012) also proposes to assess the CSR efficiency by directions. However, the author's rather unusual classification of directions presents the indices: expensive (assess the level of expenses on social actions), resulting (assess the effect from the implementation of social actions), structural (assess the change of the structure of a definite resource), effective (assess the ratio of result and expenses) [18].

In the articles of Buian (2012) special attention is being paid to the international methods of assessment and some specific methods for the CSR assessment are singled out, i.e. World Stock Dow Jones Sustainability Index, Social Index - SI of Danish Ministry for Social Policy, Corporate Philanthropy Index, Triple Bottom Line Method, Balanced Scorecard Method, FTSE4Good Index, Domini Social Investment Index (DSI 400) and others. The researcher adds that in spite of their spreading in the countries of North America 
and the European Union, they are difficult to be used for the assessment of the CSR level concerning domestic enterprises. There are differences in directions and parameters, and each approach and method allows to analyze a definite component only or the group of CSR components [19].

In addition, at present there are variable methods for the assessment of CSR of enterprises. Kusyk (2012) states in the publications that some researchers follow the methodology developed by the Association of Russian managers with the support of UNO Development Programme in order to determine the influence of the company social responsible activities [20]. It is suggested to measure the quantitative index of business social investments:

- The index of specific social investments is the value of companies' social investments per employee;

- The ratio (share) of company social investments to the total amount of their sales (per cent);

- The ratio (share) of company social investments to the total amount of their incomes (before taxation) (per cent).

The amount of quantitative measurement of social investment index is not standardized and may have any positive values. However, the high level of index proves the high level of company social activity.

Unlike the quantitative indices of social investments, which create the picture of the phenomenon scope, the qualitative index of social investments includes the assessment of the level of complexity and fullness of such a phenomenon as corporate social responsibility. In this case, they use three groups of criteria for the quantitative assessment of social investments and these groups are based on 12 indices that allow calculating the following types of the qualitative index of social investments:

1. The qualitative index of social investments for i-company showing the level of complexity of the company social activities (per cent);

2. The qualitative index of social investments for $j$-feature showing the degree of the qualitative feature availability in the selection of companies - respondents (per cent);

3. The general qualitative index of social investments showing the level of complexity of the social activities for the company, which is researched (per cent).

All these three kinds of the qualitative indices of social investments are standardized and may accept values from $0 \%$ to $100 \%$. The value of the index is higher the more complete and integrated the company social policy is.

According to the point of view of above-mentioned article this methodology can be used for building the rating among the enterprises engaged in social responsible activities, but the model described by Shmygol (2010) is considered to be more reasonable; this model for the assessment of efficiency of social investments and corporate social responsibility was developed by the scientists from "The Institute of City Economy" and shows the calculation of the integrated index [21].

The integrated index is calculated as the ratio of the amount of paid out taxes, investments in fixed capital, and company social expenditures to the current expenses of production purposes. Besides, the indicator of perspective development is calculated as the ratio of the amount of investments in fixed capital and social expenditures to the company net profit. The indicator of social expenditures is calculated as the ratio of amount of social expenditures to the net profit for a reporting period (the index showing $1 \%$ is considered to be ordinary).

One should agree with Khlevyts'ka (2014) saying that it is necessary to apply a comprehensive, integral assessment of totality of separate indices, which reflects the key 
aspects of the company activities in the CSR area to the maximum. The methodology offered by her includes the calculation of intermediate integral indices (about economic efficiency of activities in the CSR area, about social efficiency of activities in the CSR area, about ecological efficiency of activities in the CSR area), and generalizing integral index of CSR activity efficiency [22].

The author of the article considers that the most reasonable is the determination of the significance of the indices by the expert's way that allows underestimating the objectivity of the performed calculations. In addition, the researcher does not provide the mentioned limited indices by components: economic, social, and ecological. If interpreting the obtained results of the integral assessment of efficiency of activities in the CSR area takes place and the enterprise observes all the standard values, then the value of the integral index is equal to 1 . The methodology proposed by Khlevyts'ka [22] composes the general integral index; on the other hand, this methodology is not easy enough for implementation and requires the involvement of experts.

The view of empirical investigations of corporate social responsibility dedicated to the study of relationship between corporation and society with the application of social ratings of such companies as Kinder, Lydenberg, Domini for the period before 2011 were presented by Mattingly (2017) [23]. The view generalizes 100 empirical investigations, describes their peculiarities and discrepancies, but this particular study did not allow to solve the issue methodologically.

Methodological issues relating to reporting biases and sample selection biases in CSR research are taken up by Rost and Ehrmann (2017) [24] and Shahzad and Sharfman (2017) [12] respectively. The issue concludes with a research note on the weighting of CSR dimensions by Capelle-Blancard and Petit (2017) [25].

The study of A. Crane, I. Henriques, B.W. Husted and D. Matten was dedicated to the improvement of the methodology concerning the CSR assessment on the base of quantitative methods (Crane, Henriques, Husted, Matten 2017) [26].

In our opinion, the paper published in 2018 is considered to be rather interesting investigation (Halme, Rintamäki, Knudsen, Lankoski, Kuisma, 2018) [27]. It presents the qualitative comparative analysis based on 19 big companies. It determines various ways connected to the improvement of ecological and social indices in the CSR area. It reveals two ways for improving the ecological indices: exogenous and endogenous. The paper also shows the ways of improving the social indices, which include the integration of social responsibility in main business.

\section{Results and discussion}

Performing the CSR assessment first of all it is necessary to determine the tasks of the assessment and choose the methods and use the methodology according to the purposes (strategic, current, rapid analysis), activity directions (internal CSR and external CSR), and users' needs (owners, investors, managers, stakeholders, Government). Moreover, the indices must be both quantitative and qualitative. The external rating assessment of the companies' business reputation is significant. At present, there are a number of ratings in the entire world with their criteria of assessments. However, there should be mentioned that the assessment is conducted mainly on investments, personnel, the use of corporate assets, social responsibility, the quality of management, financial sustainability, long-term investments, the quality of goods and services, etc. The information about the company activities as mentioned above is presented mostly by indices (calculation indices), which allow to 
transform a public conception concerning the company responsibility to ethical, social requirements into a specific index. They are social indices, stock, and non-stock. The concept of sustainable development singles out three directions applied for the formation of ratings and corresponds to the CSR concept:

1. Positive characteristics of the company production and economic activities;

2. Ecological characteristics and the decrease of negative impact on environment;

3. The company social development and its social policy implementation.

Moreover, there is another important point that concerns the realization and observance of the CSR standards, which influences in particular the formation of indicators in the CSR area.

\section{Development of research methodology}

According to the results of the carried out investigation, we suggest determining the integral index of corporate social activity efficiency, which will show the impact of both qualitative and quantitative indices.

The integral index will be determined by the following formula:

$$
\mathrm{I}_{\mathrm{KCB}}=\mathrm{C}_{\mathrm{CSR}}^{\text {qualit }}=\mathrm{C}_{\mathrm{CSR}}^{\text {quant }}
$$

where $\mathrm{II}_{\mathrm{CSR}}$ : the integral index of the company CSR efficiency;

$\mathrm{C}_{\mathrm{CSR}}^{\text {qualit }}$ : the coefficient of the qualitative parameters of the CSR efficiency;

$\mathrm{C}_{\mathrm{CSR}}^{\text {quant }}$ : the coefficient of the quantitative parameters of the CSR efficiency.

$$
\mathrm{C}_{\mathrm{CSR}}^{\text {quant }}=\frac{\mathrm{C}_{\mathrm{CSR}}^{\text {intern. }}+\mathrm{C}_{\mathrm{CSR}}^{\text {extern. }}}{2}
$$

where $C_{C S R}^{\text {intern }}$ : the coefficient of the internal social policy efficiency,

$\mathrm{C}_{\mathrm{CSR}}^{\text {extern }}$ - the coefficient of the external social policy efficiency,

$$
\mathrm{C}_{\mathrm{CSR}}^{\text {intern }}=\mathrm{C}_{\text {profit.asset. }} \mathrm{x} \mathrm{a}_{\text {profit.asset. }}+\mathrm{C}_{\mathrm{S}} \times \mathrm{a}_{\mathrm{s}}+\mathrm{C}_{\mathrm{EISP}} \mathrm{X} \mathrm{a}_{\mathrm{EISP}}+\mathrm{C}_{\mathrm{ETR}} \mathrm{x} \mathrm{a}_{\mathrm{ETR}}
$$

where $\mathrm{C}_{\text {profit.asset. }}$ : the coefficient of changing the company assets profitability;

$\mathrm{C}_{\mathrm{S}}$ : the coefficient of changing the company employees' average monthly salary;

$\mathrm{C}_{\mathrm{EISP}}$ : the coefficient of changing the expenses on internal social programmes;

$\mathrm{C}_{\mathrm{ETR}}$ : the coefficient of changing a part of employees' quantity who completed retraining courses or advanced training,

$a_{\text {profit.asset. }}, a_{\mathrm{s}}, a_{\text {EISP }}, a_{E T R}$ : the significant coefficients showing the importance of the parameter when the internal CSR efficiency assessment takes place.

$$
\mathrm{C}_{\mathrm{CSR}}^{\text {extern }}=\mathrm{C}_{\mathrm{EESP}} \times \mathrm{a}_{\mathrm{EESP}}+\mathrm{C}_{\mathrm{EEP}} \times \mathrm{a}_{\mathrm{EEP}} \text {, }
$$

where $\mathrm{C}_{\mathrm{EESP}}$ : the coefficient of changing the expenses on external social programmes;

$\mathrm{C}_{\mathrm{EEP}}$ : the coefficient of changing the expenses on ecological programmes; $\mathrm{a}_{\mathrm{EESP}}, \mathrm{a}_{\mathrm{EEP}}$ : the significant coefficients showing the importance of each parameter when the CSR efficiency assessment takes place.

Dumova L.V. mentions that the qualitative features of the CSR efficiency are mainly based on the regulations of international organization «Global Initiative on Reporting» and contain such criteria as the availability of the collective contract; the availability of general 
papers regulating the company CSR activities; the availability of annual public reporting on the company social activities and its publication on the site; the availability of the appropriate department (in the organizational structure), which is responsible for the company social activities (Dumova, 2014) [24].

Examining the qualitative features according to the levels of the CSR development, we may single out the most important ones:

- the first level (basic). The observance of the requirements for this basic level allows the enterprise to run its activities within the limits of the obligatory legislative requirements and ethical rules of business;

- $\quad$ the second level (the level of charitable / or sponsoring activities);

- the third level (the level of company responsibility before internal and external stakeholders). The public reporting on social activities and placing the results on the company site and in mass media;

- the fourth level (the level of strategic direction of CSR and social investments). Observance of three mentioned above CSR levels allows the companies to reach the qualitatively new level of the CSR development, i.e. implementation and observance of the CSR European standards. The development of the strategy of social responsible measures and its integration in the company development strategy;

- $\quad$ the fifth level (the level of the CSR synergistic effect). Not all companies can reach the fifth level of the development. That is why we are not going to use it for the assessment. According to the presence or absence of the features, which are presented for each level, the value of $K_{\mathrm{CSR}}^{\text {qualit }}$ coefficient is determined.

Determining of the influence of the CSR on the business reputation of the company (Lahuta, 2017) [29] was conducted according to the results of questioning of 18 food industry enterprises. The value of the coefficient of qualitative parameters was determined basing on the level of development of the CSR. The figures are presented in the Table 1.

Table 1

Measurement of the coefficient of qualitative parameters according to the CSR level at an enterprise*

\begin{tabular}{|l|l|c|}
\hline $\begin{array}{c}\text { Level } \\
\text { of development }\end{array}$ & \multicolumn{1}{|c|}{ Requirements } & $\begin{array}{c}\text { Value of the coefficient of } \\
\text { qualitative parameters } C_{\text {CSR }}^{\text {qualit }}\end{array}$ \\
\hline The first level & $\begin{array}{l}\text { Observance of the features of the first } \\
\text { level }\end{array}$ & 0,25 \\
\hline The second level & $\begin{array}{l}\text { Observance of the features of the first } \\
\text { level and additional ones of the } \\
\text { second level }\end{array}$ & 0,5 \\
\hline The third level & $\begin{array}{l}\text { Observance of the features of the first } \\
\text { and second levels and additional ones } \\
\text { of the third level }\end{array}$ & \\
\hline The fourth level & $\begin{array}{l}\text { Observance of the features of all } \\
\text { previous levels and additional ones } \\
\text { of the fourth level }\end{array}$ & \\
\hline
\end{tabular}

*Note: compiled by the authors 
The quantitative indices of the CSR efficiency determined according to the development directions are divided mainly into two big groups:

1. Internal CSR (personnel and owners, quality and innovation, labour protection and safety);

2. External CSR (local communities, ecology)

The quantitative indices are coefficients determined as the ratio of the corresponding indices in the analyzing and basic periods. For the parameters, which are measured by valuable indices, we take into account the inflation index through the use of the discounting coefficient (Id). We developed the system of indices for determining the coefficients of measurement for the quantitative parameters of the company CSR efficiency, which includes economic, social, and ecological constituents (Table 2).

The coefficients of significance determined due to the results of the conducted questioning are equal by two criteria (assets profitability and average monthly salary $-0,25$ ), the index of expenses on internal social programmes in experts' opinion is considered to be the most important, that is why it possesses 0,3 . The index characterizing a part of employees who completed re-training courses or advanced training shows the lowest coefficient of significance $-0,2$. The indices concerning innovative activities, the quality of goods, and anti-corruption activities possess qualitative characteristics, thus these indices were already included into the group of qualitative parameters.

To assess the external CSR we use such quantitative indices as the expenses on external social programmes and expenses on ecological programmes.

Experts consider the used indices to be equal in value, thus weighting coefficients of their significance are 0,5 . The value of these coefficients is determined by the expert way and depends on the company peculiarity, thus the assessment model itself obtains the features of universality.

Taking into account the results of the previous investigations (Lahuta, 2018) [30], we determine the following levels of the CSR development:

when:

$0<I I_{C S R} \leq 0,25$ - the enterprise possesses the low level of the CSR efficiency, or when $I_{\text {CSR }}=0,-$ such activities are absent (initial I level);

$0,25<I I_{C S R} \leq 0,5-$ the enterprise realizes social policy, but on an average level (II level);

$0,5<I I_{C S R} \leq 0,75$ - the social policy of the company has the average level of social activities (III level);

$0,75<I I_{C S R} \leq 1,0-$ the enterprise possesses the high level of social activities (IV level);

$I I_{C S R}>1,0$ - the enterprise has the high level of social activities and such activities has a synergetic effect, aimed at the increasing of the company business reputation level in outdoor environment. 
Table 2

Measurement coefficients of quantitative parameters of the company CSR efficiency*

\begin{tabular}{|c|c|c|c|}
\hline $\begin{array}{l}\text { Name of group of } \\
\text { quantitative } \\
\text { parameters }\end{array}$ & Name of coefficient & $\begin{array}{c}\text { Formula for } \\
\text { calculation }\end{array}$ & $\begin{array}{c}\text { Coefficient } \\
\text { significance }(\mathbf{k})\end{array}$ \\
\hline \multicolumn{4}{|c|}{ Internal CSR } \\
\hline $\begin{array}{l}\text { Satisfaction of owners' } \\
\text { interests through the } \\
\text { company profitability }\end{array}$ & $\begin{array}{l}\text { Coefficient of changing } \\
\text { the assets profitability } \\
\left(\mathrm{C}_{\text {profit.asset. }}\right)\end{array}$ & $\frac{\mathrm{C}_{\text {profit.assets }}^{\text {act }}}{\mathrm{C}_{\text {profit.asset }}^{\text {baz }}}$ & 0,25 \\
\hline $\begin{array}{l}\text { Satisfaction of } \\
\text { personnel's interests }\end{array}$ & $\begin{array}{l}\text { Coefficient of changing } \\
\text { the employees' average } \\
\text { monthly salary }\left(\mathrm{C}_{\mathrm{S}}\right)\end{array}$ & $\frac{\mathrm{C}_{\mathrm{S}}^{\mathrm{act}}}{\mathrm{C}_{\mathrm{S}}^{\mathrm{baz}} \times \mathrm{I}_{\mathrm{d}}}$ & 0,25 \\
\hline $\begin{array}{l}\text { Social investments on } \\
\text { internal programmes } \\
\text { (labour protection, } \\
\text { working conditions etc.) }\end{array}$ & $\begin{array}{l}\text { Coefficient of changing } \\
\text { the expenses on internal } \\
\text { social programmes } \\
\left(\mathrm{C}_{\mathrm{EISP}}\right)\end{array}$ & $\frac{\mathrm{EISP}_{\mathrm{act}}}{\mathrm{EISP}_{\mathrm{baz}} \times \mathrm{I}_{d}}$ & 0,3 \\
\hline Personnel development & $\begin{array}{l}\text { Coefficient of changing a } \\
\text { part of employees who } \\
\text { completed re-training } \\
\text { courses or advanced } \\
\text { training }\left(C_{\text {ETR }}\right)\end{array}$ & $\frac{\mathrm{C}_{\mathrm{ETR}}^{\text {act }}}{\mathrm{C}_{\mathrm{ETR}}^{\text {baz }}}$ & 0,2 \\
\hline \multicolumn{4}{|c|}{ External CSR } \\
\hline $\begin{array}{l}\text { Social investments in } \\
\text { outdoor environment }\end{array}$ & $\begin{array}{l}\text { Coefficient of changing } \\
\text { the expenses on external } \\
\text { social programmes } \\
\left(C_{\text {EESP }}\right)\end{array}$ & $\frac{\mathrm{EESP}_{\mathrm{act}}}{\mathrm{EESP}_{\mathrm{baz}} \times \mathrm{I}_{\mathrm{d}}}$ & 0,5 \\
\hline $\begin{array}{l}\text { Social investments on } \\
\text { ecological programmes }\end{array}$ & $\begin{array}{l}\text { Coefficient of changing } \\
\text { the expenses on } \\
\text { ecological programmes } \\
\left(\mathrm{C}_{\mathrm{EEP}}\right)\end{array}$ & $\frac{\mathrm{EEP}_{\mathrm{act}}}{\mathrm{EEP}_{\mathrm{baz}} \mathrm{x} \mathrm{I}_{\mathrm{d}}}$ & 0,5 \\
\hline
\end{tabular}

*Note: compiled by the authors

\section{Analysis of caculations}

The calculations on this model were tested on five companies of food industry in Ukraine. Indicators for determining the efficiency coefficients and the quantitative parameters for calculating the integral indicator of CSR efficiency are presented in Tables 3. The results of calculation for the integral index of corporate social responsibility efficiency are shown in Table 4 and presented in Figure 1. 
Indices for determination of the coefficients of qualitative and quantitative parameters to calculate the integral index of CSR efficiency of enterprises for 2015-2017

Table 3

\begin{tabular}{|c|c|c|c|c|c|c|c|c|c|c|c|c|c|c|c|}
\hline \multirow[t]{2}{*}{ Indices } & \multicolumn{3}{|c|}{$\begin{array}{c}\text { JSC } \\
\text { «Zhytomyr Butter } \\
\text { Processing and Packing } \\
\text { Factory» }\end{array}$} & \multicolumn{3}{|c|}{$\begin{array}{c}\text { JSC } \\
\text { «Zhytomyr Integrated } \\
\text { Bakery» }\end{array}$} & \multicolumn{3}{|c|}{$\begin{array}{c}\text { LLC } \\
\text { «Organic Milk» }\end{array}$} & \multicolumn{3}{|c|}{$\begin{array}{c}\text { LLC } \\
\text { «Zhytomyr Meat } \\
\text { Processing and Packing } \\
\text { Factory» }\end{array}$} & \multicolumn{3}{|c|}{$\begin{array}{c}\text { JSC } \\
\text { «Beer-Alcohol-Free } \\
\text { Plant «Radomyshl'» }\end{array}$} \\
\hline & 2015 & 2016 & 2017 & 2015 & 2016 & 2017 & 2015 & 2016 & 2017 & 2015 & 2016 & 2017 & 2015 & 2016 & 2017 \\
\hline $\begin{array}{l}\text { Enterprise's assets } \\
\text { profitability*,\% }\end{array}$ & 12,1 & 14,7 & 15,3 & $-21,2$ & $-30,8$ & $-21,0$ & 14,8 & 16,8 & 17,3 & 1,6 & 0,8 & 5,3 & $-2,1$ & $-9,5$ & 1,3 \\
\hline $\begin{array}{l}\text { Employee's average } \\
\text { monthly salary, thousand } \\
\text { monetary units }\end{array}$ & 6200 & 6580 & 8900 & 2320 & 2537 & 3400 & 4050 & 4652 & 4900 & 4500 & 4800 & 5300 & 5490 & 6800 & 7070 \\
\hline $\begin{array}{l}\text { Expenses on internal } \\
\text { social programmes, } \\
\text { thousand monetary units }\end{array}$ & 95320 & 112780 & 56300 & 1200 & 2766 & 1450 & 850 & 1250 & 970 & 1100 & 1230 & 1200 & 256 & 989 & 950 \\
\hline $\begin{array}{l}\text { Part of employees who } \\
\text { completed re-training } \\
\text { courses or advanced } \\
\text { training, \% to general } \\
\text { amount of employees }\end{array}$ & 15,1 & 14,1 & 18,4 & 8,2 & 2,3 & 7,9 & 5,1 & 5,4 & 8,3 & 2,0 & 4,1 & 10,1 & 12,1 & 11,2 & 8,7 \\
\hline $\begin{array}{l}\text { Expenses on external } \\
\text { social programmes, } \\
\text { thousand monetary units }\end{array}$ & 860,5 & 1112,1 & 1500,6 & 88,1 & 100,2 & 90,7 & 230,2 & 210,4 & 270,4 & 330,8 & 310,7 & 390,7 & 450,1 & 560,4 & 778,4 \\
\hline $\begin{array}{l}\text { Expenses on ecological } \\
\text { programmes, thous. hrv. }\end{array}$ & 678,0 & 560,9 & 847,5 & 123,1 & 100,9 & 88,9 & 67,9 & 69,7 & 88,9 & 98,7 & 110,5 & 125,4 & 256,8 & 240,5 & 334,8 \\
\hline $\begin{array}{l}\text { Average inflation index } \\
\text { per year**, } \%\end{array}$ & 143,3 & 112,4 & 113,7 & 143,3 & 112,4 & 113,7 & 143,3 & 112,4 & 113,7 & 143,3 & 112,4 & 113,7 & 143,3 & 112,4 & 113,7 \\
\hline
\end{tabular}

*If the value of profitability index gets " - ", then we calculate the value of the coefficients as zero.

**Index data was obtained according to the information [31]. 
Integral index of corporate social responsibility efficiency of Ukrainian companies for $2015-2017 *$ (according to the results of selection)

\begin{tabular}{|c|c|c|c|c|c|}
\hline Years & \multicolumn{5}{|c|}{ Value of integral index for companies } \\
\cline { 2 - 6 } & $\begin{array}{c}\text { JSC } \\
\text { «Zhytomyr } \\
\text { Butter } \\
\text { Processing } \\
\text { and Packing } \\
\text { Factory» }\end{array}$ & $\begin{array}{c}\text { JSC } \\
\text { «Zhytomyr } \\
\text { Integrated } \\
\text { Bakery» }\end{array}$ & $\begin{array}{c}\text { LLC } \\
\text { «Organic } \\
\text { Milk» }\end{array}$ & $\begin{array}{c}\text { LLC } \\
\text { «Zhytomyr } \\
\text { Meat } \\
\text { Processing } \\
\text { and Packing } \\
\text { Factory» }\end{array}$ & $\begin{array}{c}\text { JSC «Beer- } \\
\text { Alcohol-Free } \\
\text { Plant } \\
\text { «Radomyshl'» }\end{array}$ \\
\hline 2015 & 0,83 & 0,20 & 0,68 & 0,23 & 0,21 \\
\hline 2016 & 0,74 & 0,23 & 0,79 & 0,26 & 0,31 \\
\hline 2017 & 0,80 & 0,24 & 0,77 & 0,46 & 0,28 \\
\hline
\end{tabular}

*Note: compiled by the authors according to the results of the researches

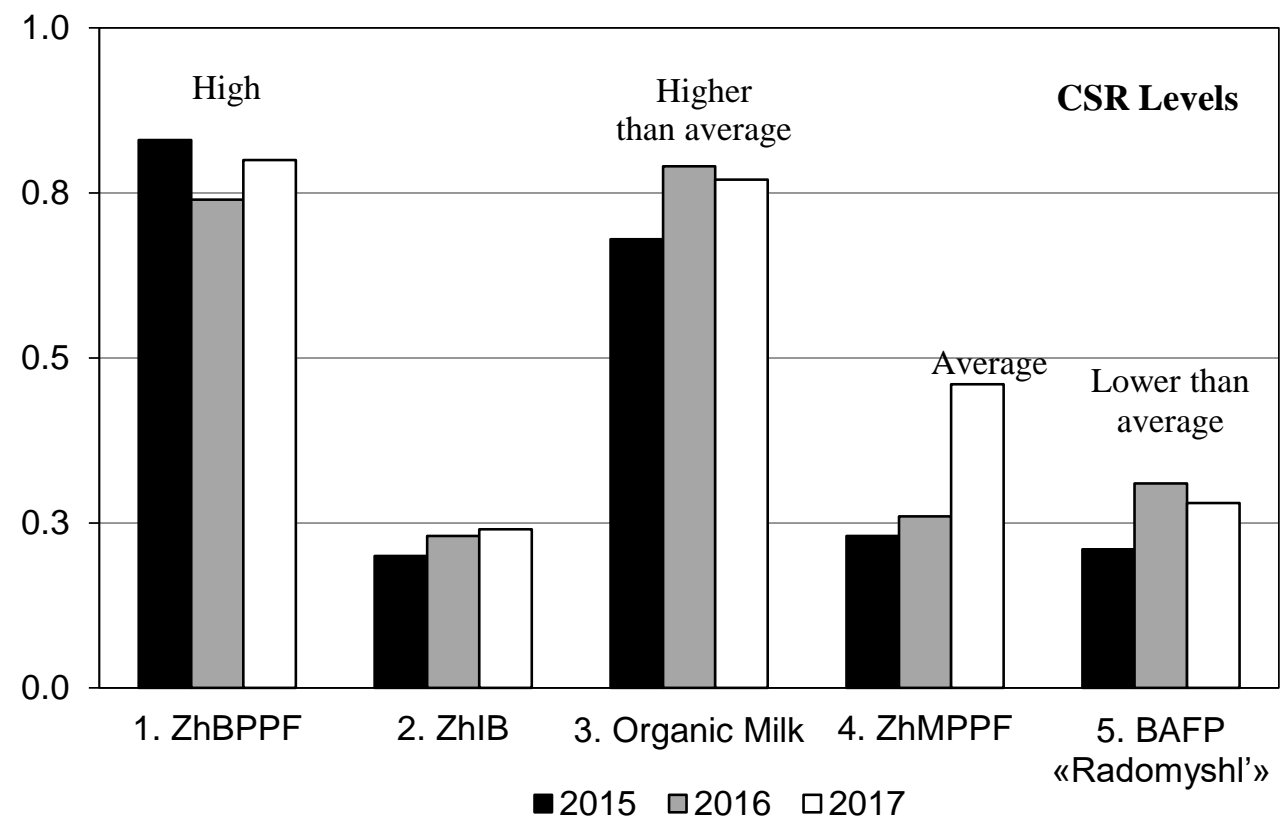

Figure 1. Value of integral index of companies' CSR efficiency for 2015-2017*

1. JSC «Zhytomyr Butter Processing and Packing Factory»

2. JSC «Zhytomyr Integrated Bakery»

3. LLC «Organic Milk»

4. LLC «Zhytomyr Meat Processing and Packing Factory»

5. JSC «Beer-Alcohol-Free Plant «Radomyshl'»

*Note: compiled by the authors according to the results of the researches 
Two companies out of three investigated ones are social active; however there are problems of strategic and management character with the CSR and management of CSR at the enterprise. Companies JSC «Zhytomyr Integrated Bakery», LLC «Organic Milk», and JSC «Beer-Alcohol-Free and Plant «Radomyshl'» have approximately equal level of social activities, however it is low and the corporate social responsibility remains on the initial level.

Such companies should direct their activities for the CSR development, namely:

1. To reach the second level. To increase the level of business reputation it is necessary to provide charities, sponsoring for educational institutions, health protection institutions, social establishments, and such stratums of population and organizations that need these actions within their possibilities;

2. To reach the third level. This is the level of the company responsibility before internal and external stakeholders. This level is characterized by increasing the level of responsibility before the interested parties. For internal stakeholders, it is the protection of owners' and investors' interests, observance of anti-corruption legislation. For personnel, the level provides the creation of additional social guarantees, social package, creation of corporate pension schemes, and organization of boarding, recreation, lodging, and medical service. The improvement of organization and culture of production in the direction of implementing international standards into the activities of the enterprise. The development of the system of internal firm programmes for training and re-training personnel, the establishment of corporate universities, and other departmental educational and health protection institutions etc. The implementation of «green office» programmes. For external stakeholders, it is the development of an honest business practice, collaboration with local communities and authorities, the development of stakeholders' map and realization of social responsible marketing etc. The public reporting about social activities and placing the results on the company site and in mass media;

3. To reach the fourth level (the level of the CSR strategic direction and social investments). The implementation and observance of national and European CSR standards. The development of strategy for social responsible actions and its integration into the company development strategy. Inclusion in the company development strategic map. The CSR principles are integrated into a mission, a strategy, a corporate culture. The mechanisms for strategic social investments are developed; the selection of the social projects closer to the company business is taken place. This level of development provides the building of the purposeful long-term programme of the company socio-economic and ecological policy within the area of its activities aimed at the solution of socially important targets, participation in public-private partnership programmes, transition to purpose-oriented social investments on both national and regional levels (Stverkova, Pohludka, Kurowska-Pysz, Szczepańska-Woszczyna, 2018; Meyer, Molefe, De Jongh, 2018) [32, 33]. Participation in solving urgent issues on the state level (poverty alleviation, the development of education, decreasing the unemployment level, the solution the problems concerning security etc.).

\section{Conclusion}

Thus there has been improved the methodology for the determination of the CSR efficiency integral index by using the system of qualitative and quantitative parameters of the CSR assessment, which unlike the existing ones, takes into account the indices of the internal and external CSR form and corresponds to the stakeholders' theory. The authors focus on 
the significance of determination of the integral index which would take into account the indices by the directions of corporate activities, meet the consumers' needs, and first of all the needs of stakeholders, and also include the indices by such three principal components as economic, social, and ecological according to the principles of providing sustainable development. The value of the integral index allows determining the level of the company CSR development and can be used for building the ratings of socially responsible companies.

\section{References}

1. Bowen G. (1953), Social Responsibilities of the Businessman, Harper \& Row, New-York.

2. Bartok O. (2018), The Use of CSR in E-Commerce as a Way to Compete, Journal of Competitiveness, 10(4), pp. 5-20, DOI:10.7441/joc.2018.04.01.

3. Burianová L., Paulík J. (2014), Corporate Social Responsibility in Commercial Banking - A Case Study from the Czech Republic, Journal of Competitiveness, 6(1), pp. 50-70. DOI: 10.7441/joc.2014.01.04.

4. Khoma I., Moroz L., Horyslavets P. (2018), Diagnostics of Conflicts within the Business Social Responsibility Forming System, Journal of Competitiveness, 10(3), pp. 16-33, DOI: 10.7441/ joc.2018.03.02.

5. Rajnoha R., Lesníková P. (2016), Strategic Performance Management System and Corporate Sustainability Concept - Specific Parametres in Slovak Enterprises, Journal of Competitiveness, 8(3), pp. 107-124, DOI: 10.7441/joc.2016.03.07

6. Freeman R.E., Harrison J.S., Wicks A.C. (2007), Managing for stakeholders: Survival, reputation, and success, Yale University Press.

7. Agle B.R., Donaldson T., Freeman R.E., Jensen M.C., Mitchell R.K., Wood D.J. (2008), Dialogue: Toward superior stakeholder theory, Business Ethics Quarterly, 18(2), pp. 153-190, available at: https://www.cambridge.org/core/journals/business-ethicsquarterly/article/dialogue-toward-superior-stakeholder-theory/21556.

8. Schwartz M.S., Carroll A.B. (2008), Integrating and unifying competing and complementary frameworks: The search for a common core in the business and society field, Business \& Society, 47(2), pp. 148-186.

9. Harrison J.S., Bosse D.A., Phillips R.A. (2010), Managing for Stakeholders, Stakeholder Utility Functions, and Competitive Advantage. Strategic Management Journal, 31, pp. 58-74, DOI: $10.1002 / \mathrm{smj} .801$

10. Bénabou R., Tirole J. (2010), Individual and corporate social responsibility. Economica, 77, pp. 1-19.

11. Bettis R.A., Helfat C.E., Shaver J.M., Zhao X., Murrell A.J. (2016), Revisiting the corporate social performance-financial performance link: A replication of Waddock and Graves. Strategic Management Journal, Wiley Blackwell, 37(11), pp. 2378-2388.

12. Shahzad A.M., Sharfman M.P. (2017), Corporate Social Performance and Financial Performance: Sample-Selection Issues: Business \& Society, 56(6), pp. 889-918, available at: https://doi.org/10.1177/0007650315590399

13. Robbins, S.P. and Coulter, M. (2007), Management. 9th Edition, Prentice-Hall, London.

14. Nikitina L., Borzakov D. (2015), Corporate Social Responsibility, Feniks, Rostov N/D.

15. Global Reporting Initiative. Guide on Reporting in the Field of Sustainable Development G4 available at: https://www.globalreporting.org/resourcelibrary/Russian-G4-Part-Two.pdf

16. Beliaeva I. Yu. \& Eskindarova M. A. (2015), Corporate Social Responsibility, KNORUS, Mins'k.

17. Vorona O.V. (2015), Methodical Approaches to the Assessment of Corporate Responsibility Level, Herald of Economy of Transport and Industry, 30, pp. 127-133. 
18. Levyts'ka Ye. H. (2012), Methodical Approach to the Development of Programme on Socially Responsible Management for a Company Providing Services, Sustainable Development of Economy: All-Ukrainian Research-and-Production Journal, 2, pp. 212-216.

19. Buian O. A. (2012), Approaches to the Assessment of Enterprises' Corporate Social Responsibility Efficiency in Ukraine, available at: http://www.vestnikdnu.com.ua/archive/201262/159-165.pdf

20. Kusyk H.L., Kovalevska A.V. (2012), Critical Analysis of Methods for the Assessment of Efficiency of Company Socially Responsible Activities, available at: http://dspace.onu.edu.ua:8080/handle/123456789/4714

21. Shmyhol' N.M. (2010), CSR - Profit : Determination, Assessment, Efficiency available at: http://www.nbuv.gov.ua/portal/soc_gum/Nvbdfa/2010_1/1, 2818

22. Khlevyts'ka T.B. (2014), Methodical Approach to the Assessment of Enterprises' Corporate Social Activity Efficiency on the Integrated Base available at: https://core.ac.uk/download/pdf/32608439.pdf

23. Mattingly J.E. (2017), Corporate Social Performance: A Review of Empirical Research Examining the Corporation-Society Relationship Using Kinder, Lydenberg, Domini Social Ratings Data, Business \& Society, 56(6), pp. 796-839, DOI: 10.1177/0007650315585761.

24. Rost K., Ehrmann T. (2017), Reporting Biases in Empirical Management Research: The Example of Win-Win Corporate Social Responsibility, Business \& Society, 56(6), pp. 840 888, DOI: $10.1177 / 0007650315572858$

25. Capelle-Blancard G., Petit A. (2017), The Weighting of CSR Dimensions: One Size Does Not Fit All, Business \& Society, 56(6), pp. 919-943, DOI: 10.1177/0007650315620118

26. Crane A., Henriques I., Husted B.W., Matten D. (2017), Measuring Corporate Social Responsibility and Impact: Enhancing Quantitative Research Design and Methods in Business and Society Research, Business \& Society, 56(6), 787-795, available at: DOI: $10.1177 / 0007650317713267$

27. Halme M., Rintamäki J., Knudsen J.S., Lankoski L., Kuisma M. (2018), When Is There a Sustainability Case for CSR? Pathways to Environmental and Social Performance Improvements, Business \& Society, DOI: 10.1177/0007650318755648

28. Dumova L.V. (2014), Analysis and Development of Methodology for the Assessment of Efficiency of Corporate Social Responsibility Systems of Enterprises of Mining and Metallurgical Complex available at: https://www.scienceeducation.ru/ru/article/view?id=13931

29. Lahuta Ya. M. (2017), Impact of Corporate Social Responsibility on Enterprise Business Reputation, Herald of Khmel'nyts 'kyi National University. Economic Sciences. 6(3), pp. $142-$ 148. available at: http://nbuv.gov.ua/UJRN/Vchnu_ekon_2017_6(3)_30

30. Lahuta Ya.M. (2018), Development of Enterprises' Corporate Social Responsibility: thesis for obtaining the scientific degree of $\mathrm{PhD}$ in Economics, speciality 08.00.04 - Economics and Enterprises' Management. Zhytomyr: ZSTU, available at: http://elartu.tntu.edu.ua/handle/lib/25933

31. Inflation Index. Summery Table of Consumer Price Indices from 2000 to 2017, Available at: https://index.minfin.com.ua/economy/index/inflation/

32. Stverkova H., Pohludka M., Kurowska-Pysz J., Szczepańska-Woszczyna K. (2018), Crossborder enterprepreneurship in euroregion Beskydy, Polish Journal of Management Studies, 18(2), pp. 324-337, DOI: 10.17512/pjms.2018.18.2.26

33. Meyer N., Molefe K., De Jongh J.J. (2018), Managerial challenges within smes: The case of a developing region, Polish Journal of Management Studies, 18 (2), pp. 185-196, DOI: 10.17512/pjms.2018.18.2.15. 